\title{
THE ROLE OF ENTREPRENEURIAL CAMPUS IN ESTABLISHING OF STUDENTS' ENTREPRENEURIAL MINDSET AND ENTREPRENEURIAL SPIRIT
}

\author{
Mohamad Trio Febriyantoro \\ Economic \& Business Faculty, Universal University, Batam, Indonesia \\ $\underline{\text { mtriofeb@gmail.com }}$
}

Keyword : entrepreneurship, business, entrepreneurial mindset, entrepreneurial spirit

\begin{abstract}
The problem of low students' motivation for entrepreneurship becomes serious thought by various parties such as governments, universities and industries, and societies. Various ways, which need to be done to foster interest and motivation in entrepreneurship, are to change the mindset of students who have been only interested to become employees in some companies. This research uses qualitative descriptive method. This method does not test hypothesis. Universities play an important role in the formation of entrepreneurial mindset and entrepreneurial spirit with the application of curriculum and entrepreneurship-based learning, the development of entrepreneurial lesson that is not just theoretical but also the practice to create new business, it can increase the motivation and interest of the students to become entrepreneurs.
\end{abstract}

\section{INTRODUCTION}

Indonesia is the country with the fifth largest population in the world with a population of about 252 million people. The large population of Indonesia needs the contribution of entrepreneurs to improve the Indonesian economy, according to the Indonesian Ministry of Cooperatives and Enterprises, Small and Medium Enterprises increased from 1.67 percent to 3.1 percent thus the level of entrepreneurship in Indonesia has exceeded 2 percent which is the minimal amount of entrepreneurship in a country. Increasing the number of entrepreneurs in Indonesia indicates that the interest of the community for entrepreneurship continues to increase, but the number of entrepreneurs in Indonesia is still less when compares with neighboring countries such as Malaysia 5 percent and Singapore 7 percent. Entrepreneurship becomes an important issue for a nation's economy. The economic progress of a nation will be determined by the existence and role of the entrepreneur.

Some developed countries are supported by a number of young people and entrepreneurial societies, in the Continent of Europe and the United States, every ten minutes the birth of new entrepreneurs (Saiman, 2009). Entrepreneurs play an important role in improving the economy for a country, so the more a country has an entrepreneur, the more the economy increases. Entrepreneurship is the right solution to solve the problem of unemployment in Indonesia. Currently only armed with a diploma is not enough, considering the graduates of college who became unemployed by 606,939 (BPS, 2017). Graduates from reputable universities also do not guarantee the students will be accepted to work in some companies. Students need to be given the provision of entrepreneurship skills because the current supply of college graduates is not proportional to the available job opportunities (Ciputra, 2010).

Table 1

Open Unemployment Rate in Riau Province

\begin{tabular}{cccc}
\hline \multirow{2}{*}{ Province } & \multicolumn{3}{c}{$\begin{array}{c}\text { Open Unemployment Rate in Riau Province } \\
\text { (Percent) }\end{array}$} \\
\cline { 2 - 4 } & $\mathbf{2 0 1 6}$ & $\mathbf{2 0 1 5}$ & $\mathbf{2 0 1 4}$ \\
& August & August & August \\
Riau Province & 7.69 & 6.2 & 6.69 \\
& & & \\
\hline
\end{tabular}

Source: Badan Pusat Statistik (2017)

The table above shows an increase in the number of unemployed in Riau Province, in 2014 unemployment in Riau Islands by 6.69 percent and then the unemployment rate in 2015 dropped at 6.2 percent and in 2016, there was a drastic increase of 7.69 percent. The number of unemployed becomes a serious threat for all parties, so the need for the community is equipped with knowledge about entrepreneurship. The cause of the lack of interest of students to become entrepreneurs is now a serious problem for various parties namely government, 
educational institutions, industry, and society. Various efforts are made to cultivate interest in entrepreneurship by changing the mindset of the students who had been only willing to become employees. Therefore, it is a challenge for universities to produce graduates who can contribute to the creation of the field of work. Growing the entrepreneurial spirit of the students through entrepreneurship education becomes a college task because it is believed that entrepreneurship education is an alternative way to reduce the unemployment rate, because undergraduate graduates are expected as not only workers but also need to be job creators.

According to Zimmerer (2002), one of the factors, driving the growth of entrepreneurship in a country lies in the role of universities through the implementation of entrepreneurship education. The university is responsible for educating and giving entrepreneurship skills to its graduates and motivating them to dare to choose entrepreneurship as their career. The roles of universities in creating graduates become an entrepreneur. This will have an impact on increasing entrepreneurship among undergraduates and reducing the number of unemploy in Indonesia.

Currently, several universities in Indonesia have incorporated entrepreneurship courses into the curriculum and as one of the compulsory subjects undertaken by all students. Entrepreneurship education not only provides theoretical knowledge only but the importance of shaping attitude, behavior, and mindset of an entrepreneur. This is a valuable lesson for students to prepare and start a business through experiences, skills and knowledge to develop and expand a business. Entrepreneurship education can motivate students to choose to become entrepreneurs as a career option in addition to being an employee.

Entrepreneurship needs to be given to someone in a good educational system and is expected to have great potential to become an entrepreneur. The influence of entrepreneurship education by using designed thinking has an influence in increasing the motivation to entrepreneurial mindset for students, entrepreneurial motivation of students can be stimulated by using case study or real business (Daniel, 2016).
Research on Entrepreneurial Spirit (Marlina, 2012) aims to find out some of the causes of undeveloped business entrepreneurship by young entrepreneurs. These results and studies find some causes of undeveloped business due to lack of market sensitivity, weakness in calculated risk taker, and lack of passion for entrepreneurship, and persistent. The importance of the role for young entrepreneurs to continue to grow entrepreneurial spirit, especially passion, market sensitivity, calculated risk taker, persistence. The entrepreneurial spirit character that must be owned by students becomes the main foundation that can strengthen them in running their business during the education process in university.

Entrepreneurial spirit according to Ciputra (2011) is a passion which has a high spirit to pursue their dreams, independent of being able to independently realize their dreams, the opportunity creation is to understand that in realizing their dreams they should pay attention to customer or market factors, a good product / service according to them certainly good according to the customer or market, creative and innovative is able to creatively find the gap and way out to realize the dream, this creativity must be appreciated also by the customer or market so that it can be called innovative, calculated risk taker is brave to take risks with careful consideration, persistence is an unyielding attitude in the face of every obstacle, high ethical standards that have ethical standards in business, is needed to be able to do business in the long run.

\section{METHOD}

This research uses qualitative descriptive method, which does not test or generalize a hypothesis. Qualitative descriptive research is a study that aims to describe, summarize the various conditions, various situations, or various phenomena of social reality that exist in society that become the object of research and see various events to the surface as character, character, nature, model, sign, or picture about certain conditions, situations and phenomena (Bungin, 2011).

Meanwhile, according to Nana Syaodih Sukmadinata (2011), qualitative descriptive research 
is intended to describe and describe the existing phenomena, both natural and human engineering, which is more concerned about the characteristics, quality, and interrelationship between activities. In addition, descriptive research does not provide treatment, manipulation or alteration on the variables studied, but rather describes a condition as it is. This research is done through observation, interview, and documentation. In the opinion of the experts above can be concluded that qualitative descriptive research, as a series of activities to obtain data that is without in certain conditions that result more emphasis on meaning. Here, researchers use descriptive qualitative research method because this research explores the phenomenon of the process of forming entrepreneurial mindset and entrepreneurial spirit through the role of entrepreneurial campus in university students of Universal University.

In qualitative research, the population term is not used. The sampling technique used by the researcher is purposive sample. Purposive sample is a technique of determining the sample with certain consideration (Sugiyono, 2012) in the research (Febriyantoro, 2016). According to Arikunto (2010), the selection of samples by using purposive methods in this study based on the requirements, which must be met as follows:

a) Sampling contains certain characteristics, traits and characteristics, which characterize the population.

b) The subjects are taken as the samples with the most characteristics of the population.

c) Determination of population characteristics is done carefully in the preliminary study.

Students become informants in accordance with criteria relevant to the research problem. The designated informant has been set before the data collection, depending on the available resources and time, as well as the research objectives (Bungin, 2011). So on the basis of the criteria of informants in this study are ten students of Universal University Management major, which has been at least two years of study with the assumption that has obtained enough education, and knowledge of entrepreneurship, has run a business in entrepreneurship lessons. Interviews were conducted using in-depth interview method of university students. Each informant is given the same questions related to the role of entrepreneurship lesson in shaping the character of entrepreneurial spirit in each individual informant.

To avoid any difference of understanding or double meaning between informant and researcher then at the end of research done triangulation with method check which is process of comprehension test and check by researcher to informant with aim to know conformity data submitted by informant. Validity test or validity is done by asking informants to re-read the results of research related to information that has been informant given earlier in the interview process.

According to Bognan \& Biklen (1982) the qualitative analysis cited by Moloeng (2007), is an attempt done by working with data, organizing data, sorting it into manageable units, searching and finding patterns, finding something important, and decide what data can be shared with others. The above analysis can be concluded that the initial step in analyzing data that is collecting existing data, organizing systematically, and presenting the results of his research to others.

Data analysis uses in-depth interview with informant, which is someone who really understand and know situation of research object. The research begins by conducting in-depth interviews to the informant and then the data is analyzed by transcribing the interview results, replaying the interview recordings, listening carefully, and then writing the words that are heard according to what is in the recording.

After the researchers describe the results of the interview into the transcript, then researchers need to read carefully and then done data reduction. The researcher reduces the data by making the abstract, taking and recording useful information in accordance with the research or ignoring unnecessary words so that the sentence is obtained only, but the language corresponds to the language of the informant. 


\section{DISCUSSION}

In this research, using qualitative methods with data analysis is a useful stage to review data, which has been obtained from some informants who have been selected during the study, took place. It is also useful for explaining and ensuring the correctness of research findings. This data analysis has been done since the beginning and together with the data collection process in the field.

Informants of this research are University of Universal Students who have been educated for at least a year and has run their own business. There are two types of data used in this study, namely primary and secondary data. Primary data were obtained directly from informants, while secondary data were obtained through literature and written data. Data were collected through in-depth interviews.

Based on the observation and search of informants conducted the researchers managed to obtain informants who meet the requirements of Universal University Students who have a minimum education for a year and at least have run and understand about entrepreneurship. Informant identity as follows:

Table 2.

Informant Identity

\begin{tabular}{|c|l|c|}
\hline No & \multicolumn{1}{|c|}{ Name } & Semester \\
\hline 1 & Irvan Suryadi & 5 \\
\hline 2 & Hendri Gustiady & 5 \\
\hline 3 & Chasdy & 5 \\
\hline 4 & Afriyani & 5 \\
\hline 5 & Verina & 5 \\
\hline 6 & Candra Adi Putra & 5 \\
\hline 7 & Vivian & 5 \\
\hline 8 & Deddy Andika & 5 \\
\hline 9 & Agus Saputra & 3 \\
\hline 10 & Bukari & 3 \\
\hline
\end{tabular}

Source: Primary data processed, (2017)

All informants have run their business, some of which choose food and beverage industry, beauty, tourism, craft and fashion. Some informants choose the industry because they already have expertise in the field and they have passion to run their business.

\subsection{Entrepreneurial Campus and Entrepreneurial Mindset}

In the college, informants have an important role in building entrepreneurial mindset, Universal University instill entrepreneurial thinking since students take business introduction lessons, in introductory lessons of business students rather than learning about business theory in general but students gain understanding about entrepreneurship. At the end of the semester, students prepare business ideas that have creative and innovative elements, so that students learn the business is not just theory but will give birth to business ideas that will be developed in the next semester.

Irvan Suryadi expresses the following statement about the role of entrepreneurial campus in building entrepreneurial mindset.

"... I get a lot of understanding and entrepreneurial thinking from some lessons like introductory management and some other lessons, we are not just fixated on theory but we are almost like real practice, like business simulation, business model making canvas and so on, I get a lot lessons for becoming a successful entrepreneur."

In addition to the application of entrepreneurship in several subjects, some informants stated that the support of universities in supporting the activities of students in entrepreneurship could also build a mindset for entrepreneurship. Following statement given by Deddy Andika regarding campus support in student activities, is:

"... Universal University always supports all the activities of students, especially in entrepreneurial activities, so as a student it becomes a motivation to continue to entrepreneurship."

Verina also feels the same thing about the influence of the campus in the formation of entrepreneurial mindset in the students.

"... We are required to think creatively and try to find new ideas, so in some lessons we are required to form teams and think about new products, we feel 
challenged with it, so the mindset of an entrepreneur will imprint on every student."

Another opinion was also expressed by Chandra Adi regarding the role of campus in changing the mindset of students from previously only interested to be employees but with entrepreneurial-based learning opened the minds of students about career as an entrepreneur.

"... The role of college is very important in opening my insight to become an entrepreneur, I grew up from a family who also entrepreneurship so campus as my second home to increase my motivation to become an entrepreneur."

All informants stated that university play an important role in the formation of entrepreneurial thinking, because some lessons stimulate students to think creatively and innovatively and able to read opportunities. At Universal University, every 3 months there are some resource persons who have successful entrepreneurship will be invited so that this can increase student motivation to entrepreneurship. This is also reinforced by research Monry and Aliyah (2015) campus environment with entrepreneurshipbased learning affect the readiness of students in entrepreneurship. The basic pattern of entrepreneurial learning should be systemic, entrepreneurial delineation there are aspects of theory, practice, and implementation. Learning-oriented is to produce young entrepreneurs who brave to start and have the ability to read market opportunities and to manage the company. Learning must be systemic, which contains aspects of theory, practice and implementation. In addition, in the implementation of learning should be accompanied by operationalization of a relatively complete whole education such as training, guidance, coaching, consulting and so forth.

\subsection{Entrepreneurial Campus and Entrepreneurial Spirit}

The role of the campus in improving entrepreneurial spirit which consists of passion, independent, market sensitivity, creative and innovative, calculated risk taker, persistent and has high ethical standard. Students get learning about entrepreneurship based on field practice so entrepreneurial spirit will always be embedded in students. Vivian who has also run a food business discloses this.

"... On-campus learning that emphasizes entrepreneurship makes me more motivated, independent and calculated risk taker, this ability is seen in me in shaping entrepreneurial spirit."

This is also reinforced by Agus Saputra who has business in the field of tourism, considers the role of entrepreneurial learning can increase the sensitivity in reading market opportunities.

"... Learning at the beginning of the semester taught by some lecturers, emphasizing instinct in reading market opportunities, lecturers provide challenges to create products from existing problems. After learning I started practicing with what I learned in class."

Some students argue the role of universities in shaping the entrepreneurial spirit is a positive thing, because students are not just looking at a business, on theoretical concepts but the practice directly. Bukari and Chasdy reveal entrepreneurialbased learning can increase creativity.

Chasdy

"... I get a lot of lessons from some learning such as small business management and marketing management in the classroom, I get some important lessons i.e. I can pour my creativity in making a product as well as a guest lecture on digital marketing also open my mind about a product that is creative and innovative."

Bukari

“... I really like learning based on entrepreneurship at university. Some lessons are supportive with various things related to entrepreneurship; some other lessons challenge students in making products. In this university, I make my creativity more honed. Before I assume that university only learns the theory but I am very fortunate to be able to apply the learning which has been given by the lecturers."

Afriyani also expresses another opinion about the role of the campus in growing entrepreneurial spirit, especially in the spirit of persistence.

"... Some lessons, especially lessons related to entrepreneurship, lecturers always instill persistence because failure is not something to be afraid. If we 
fail we can try again to succeed, after fail we have to get up immediately, in small business management lesson we are told to make business, initially we are afraid our product will sell, but with motivation from lecturer who make us dare to try and dare to fail."

Furthermore, Hendri's opinion on the role of campus in instilling entrepreneurial spirit in entrepreneurship-based learning.

"... Almost everything in entrepreneurial spirit exists in every campus learning, such as ethics and honesty, at Universal University is strongly emphasized about ethics and honesty, everyone who runs a business must uphold ethics and honesty if the business is not based on ethics and honesty then the business will fail, many people have failed because of not uphold ethics. "

College, as a second home for students, has a role in instilling entrepreneurial mindset, with the increasingly narrow field of work to make universities experiencing dilemma. One of the alternatives is applying entrepreneurship-based learning, if the college is consistent in fostering the mindset and entrepreneurial spirit is expected. Graduates will become entrepreneurs who can create jobs and can benefit the surrounding community.

\section{CONCULUSION}

In this research, it can be concluded that the role of university in the formation of entrepreneurial mindset and entrepreneurial spirit of students with the application of entrepreneurship-based learning, entrepreneurship-based learning is a method that combines theory and practice, so students not only have an understanding theoretically but the implementation of the theories that have been described in classroom learning.

Some students said that the role of the campus is so important in shaping the mindset and entrepreneurial spirit, students in the first semester are given an understanding of entrepreneurship then in the third semester the students begin to solve the problems experienced in the past.

\section{REFERENCES}

Arikunto, S. 2010. Prosedur penelitian $\square$ : Suatu Pendekatan Praktik. (Edisi Revisi). Jakarta. Rineka Cipta.

BPS. 2017. Pengangguran Terbuka Menurut Pendidikan Tertinggi yang Ditamatkan 1986 - 2017. Retrieved from https://www.bps.go.id/linkTabelStatis/view/i $\mathrm{d} / 972$

Bungin, B. 2011. Penelitian Kualitatif: Komunikasi, Ekonomi, Kebijakan Publik dan Ilmu Social Lainnya. Jakarta: Kenncana.

Ciputra. 2011. Ciputra Quantum Leap 2. Jakarta: Elex Media Komputindo.

Daniel, A. D. 2016. Fostering an entrepreneurial mindset by using a design thinking approach in entrepreneurship education. Sage, 30(3), 215-223.

Febriyantoro, M. T. 2016. Pemikiran irasional para perokok. EKSIS, XI(2), 1907-7513.

KUKM, K. 2017. Ratio Wirausaha Indonesia Naik 3,1 persen. Retrieved from http://www.depkop.go.id/content/read/ratiowirausaha-indonesia-naik-jadi-31-persen/

Marlina. 2012. Peran market sensitivity, calculated risk taker, passion, dan persistent dalam perkembangan bisnis entrepreneur muda. In Seminar Nasional Kewirausahaan dan Inovasi Bisnis II. Jakarta: Universitas Tarumanagara.

Moloeng, L. 2007. Metodologi Penelitian Kualitatif. Bnadung: PT Remaja Rosdakarya Offset.

Ratumbuysang, M. F. N. G., \& Aliyah A. Rasyid. 2015. Peranan Orang Tua, Lingkungan, dan Pembelajaran Kewirausahaan Terhadap Kesiapan Berwirausaha. Pendidikan Vokasi, 5(1), 15-26.

Saiman, L. 2009. Kewirausahaan: teori, praktik, dan kasus-kasus. Jakarta: Salemba Empat.

Sugiyono. 2012. Memahami Penelitian Kualitatif. Bandung: Alfabeta.

Sukmadinata, N. S. 2011. Metode Penelitian Pendidikan. Bandung: PT Remaja Rosdakarya.

Zimmerer, W. T. 2002. Essentials of Entrepreneurship and Small Business Management. New York: Prentice Hall. 